\title{
Phaeochromocytoma of the Urinary Bladder
}

\author{
P MCR. HIGGINS, ${ }^{*}$ F.R.C.S. ; GERALD C. TRESIDDER, † F.R.C.S.
}

Brit. med. F., 1966, 2, 274-277

Chromaffin tissue has been reported to have been present in the wall of the bladder (Scott and Eversole, 1960), and this finding explains the occurrence of vesical phaeochromocytoma. Seventeen instances of this tumour have been described (Sivak, 1961; Poirier and Robinson, 1962 ; Blair and Branwood, 1963; Milliez et al., 1963). This means that of the extra-adrenal sites the bladder is affected less often than the organ of Zuckerkandl (in the inferior para-aortic region) and with approximately the same frequency as the posterior mediastinum. Our own case (Case 1) is the second to be reported in which metastases are known to have been present. The first such cases, that of a woman of 36 who died after cystoscopy and at necropsy was found to have a vesical phaeochromocytoma with metastases in the liver and regional lymph nodes, was described by Pugh et al. (1960). Our patient survived operation and at the time of writing was alive and well, with no evidence of recurrence. In the course of our inquiries on the subject two further cases came to light. These are presented as Cases 2 and 3 by the courtesy of Dr. Stanley E. Farley and of Mr. J. F. R. Withycombe, respectively.

\section{Case 1}

A 14-year-old schoolboy presented suffering from severe haematuria and clot-retention. A year previously he had experienced a transient episode of haematuria. At that time medical advice had not been sought. During the ensuing months he was less well than usual, often sweated for no apparent reason, felt tired, and had been noted to be pale. The only symptoms referable to the urinary tract were attacks of throbbing in the head immediately after micturition. These attacks were infrequent, lasted for a few seconds only, and did not strike him as being related to the degree of fullness of the bladder. Four weeks before admission the haematuria returned and gradually increased in severity. He was seen at other hospitals on 22 and 25 December 1964, and on these occasions his bloodpressure was $150 / 90$ and $145 / 90$. On 26 December he developed clot-retention and was admitted to the London Hospital. On admission the blood-pressure was $160 / 120$, but after catheterization the reading fell to $130 / 90$ and remained at this level until operation. He had a café-au-lait spot approximately $2 \mathrm{~cm}$. in diameter below the right nipple, but no other manifestations of neurofibromatosis were discovered.

An intravenous pyelogram showed normal excretion from both kidneys, but cystoscopy revealed a tumour on the anterior wall of the bladder. The view was unsatisfactory owing to the presence of floating debris, but the lesion appeared to be some $2 \mathrm{~cm}$. in diameter and was orange-yellow in colour. Its surface was irregular and ulcerated, but the surrounding mucosa was normal. A biopsy specimen was taken but was not helpful, as it showed necrotic tissue only. A double contrast cystogram was performed (Figs. 1 and 2). The 24-hour excretion of 4-hydroxy-3-methoxymandelic acid (vanillylmandelic acid) was $13.7 \mathrm{mg}$. (in $1,750 \mathrm{ml}$. of urine). The upper limit of normal is $8 \mathrm{mg} . / 24$ hours. Chromatography of the urine showed the principal metabolite to be normetadrenaline.

There was no family history of hypertension, and the patient's parents and his two siblings all excreted normal amounts of vanillylmandelic acid in the urine.

On admission his haemoglobin was $10.7 \mathrm{~g} . / 100 \mathrm{ml}$. (73\%) and a pre-operative transfusion of $1,200 \mathrm{ml}$. of whole blood was given. Partial cystectomy was performed on 22 January 1965, excising the tumour and 2 to $3 \mathrm{~cm}$. of the surrounding bladder wall. The

* Senior Registrar in Surgery, the London Hospital. t Consultant Urologist, the London Hospital. tumour itself measured 3.8 by 3.7 by $3.4 \mathrm{~cm}$. The peritoneum overlying the growth was removed both in order to minimize handling and to make certain of complete excision of the tumour. Several enlarged lymph nodes were seen in the region of the internal iliac arteries, and two of these were removed for section. No masses could be felt in the para-aortic and adrenal regions. At the start of the operation the blood-pressure rose to $200 / 110$ and remained at this level until the final clamp was placed, when it fell abruptly to $70 \mathrm{~mm} . \mathrm{Hg}$ systolic. Neither phentolamine nor noradrenaline was required, and the blood-pressure rose steadily during the next hour to $130 / 90$, at which level it remained for the duration of his stay in hospital (Fig. 3).

Recovery was uneventful. On the third post-operative day the 24-hour excretion of vanillylmandelic acid was $6.8 \mathrm{mg}$., falling to $3 \mathrm{mg}$. one week later. Tumour analysis showed $1.7 \mathrm{mg}$. of noradrenaline per gram of tissue: no adrenaline was present.

Histological examination confirmed the diagnosis of phaeochromocytoma, showing cells which were mainly well differentiated but
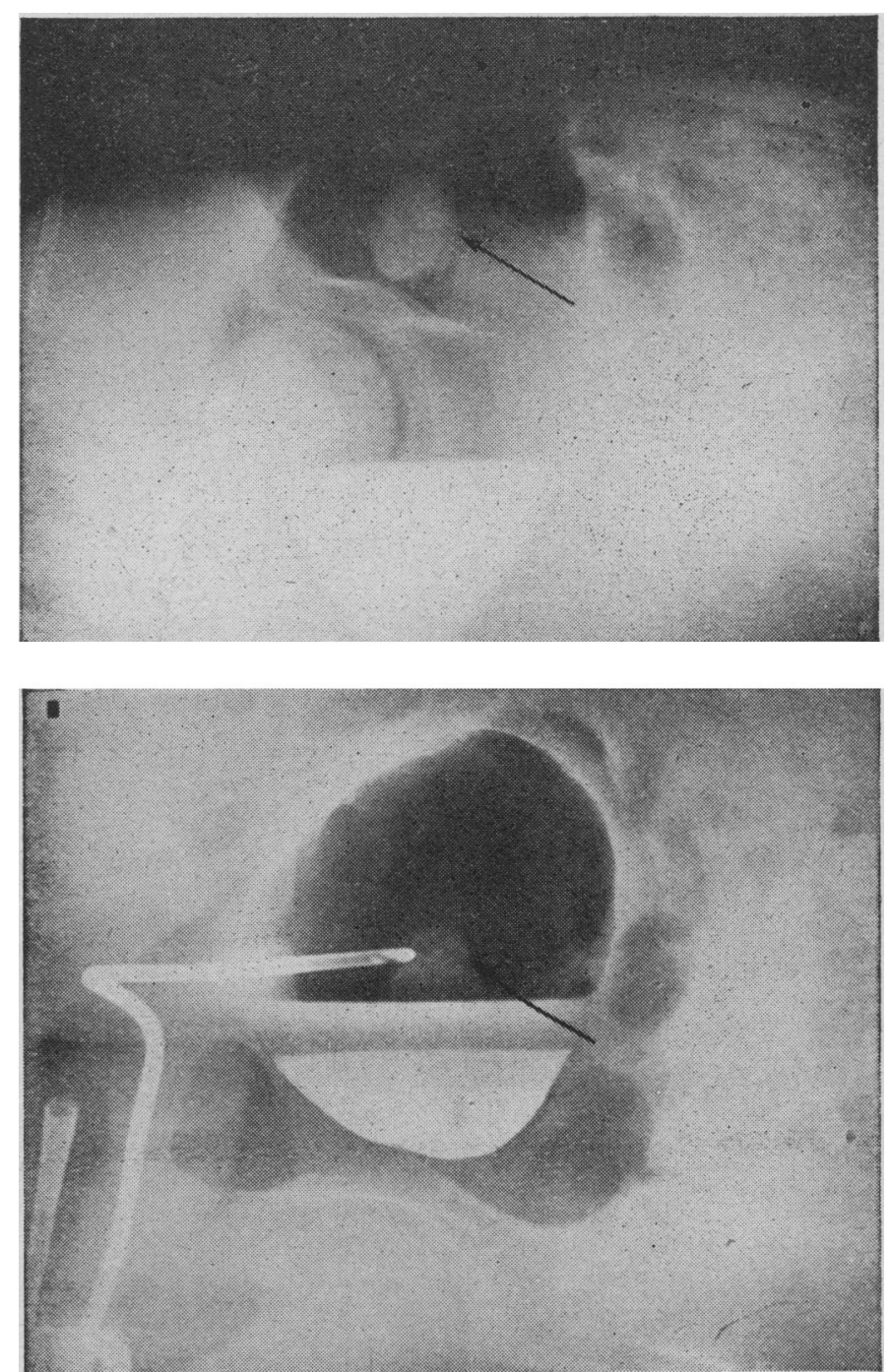

FIGS. 1 and 2.-Case 1. Double contrast cystogram (Dr. Geoffrey Key). The tumour is arrowed. 
having a few unusually large nuclei (Fig. 4). The edge of the tumour showed some lymphatic permeation and probably intravascular but still subendothelial growth. At operation the lymphnode enlargement was thought to be inflammatory in origin, but on section a metastatic deposit of phaeochromocytoma was found (Fig. 5).

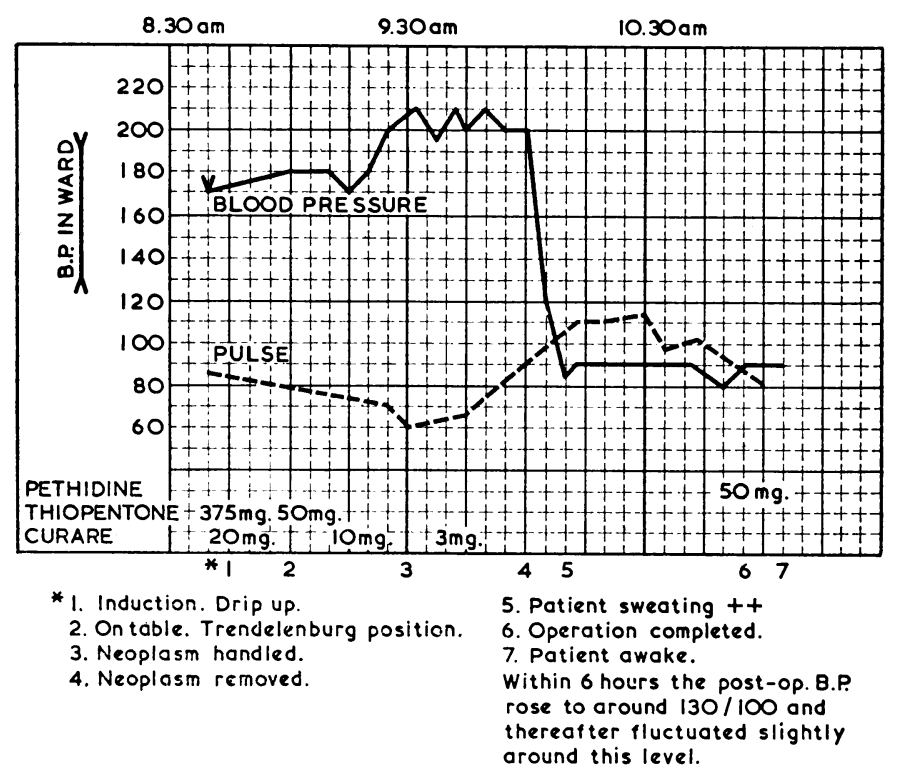

Fig. 3.-Case 1. Anaesthetic chart.

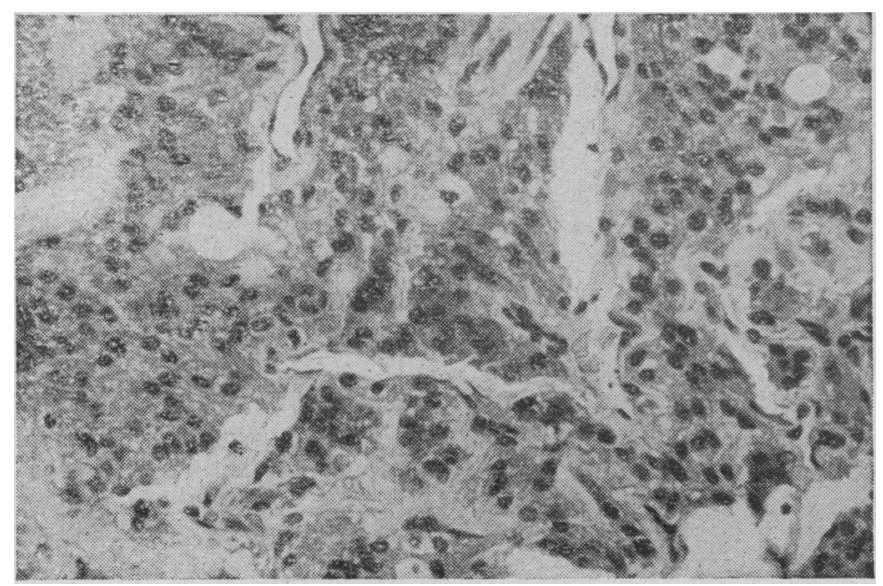

FIG. 4.-Case 1. High-power view of vesical phaeochromocytoma showing cells which are mainly well differentiated but with a few unusually large nuclei.

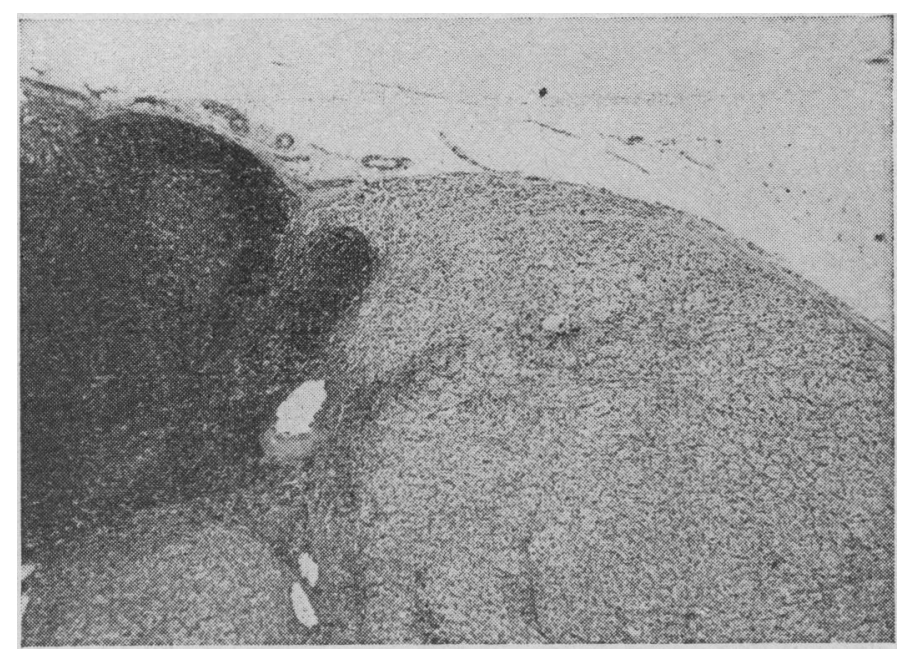

FIG. 5.-Case 1. Low-power view of iliac lymph node. Tumour cells are seen on the right.
Lymphangiography (Fig. 6) showed apparent filling defects in some of the nodes in the left internal iliac and right para-aortic regions, suggesting the possibility of further lymph-node involvement. In view of this a course of 4,000 rads was given to the para-aortic and internal iliac areas by means of the Telecobalt unit.

When last seen, nine months after operation, the patient was in excellent health, with a blood-pressure of 105/70 and a urinary vanillylmandelic acid excretion of $5.5 \mathrm{mg} . / 24$ hours. The principal metabolite was again normetadrenaline.

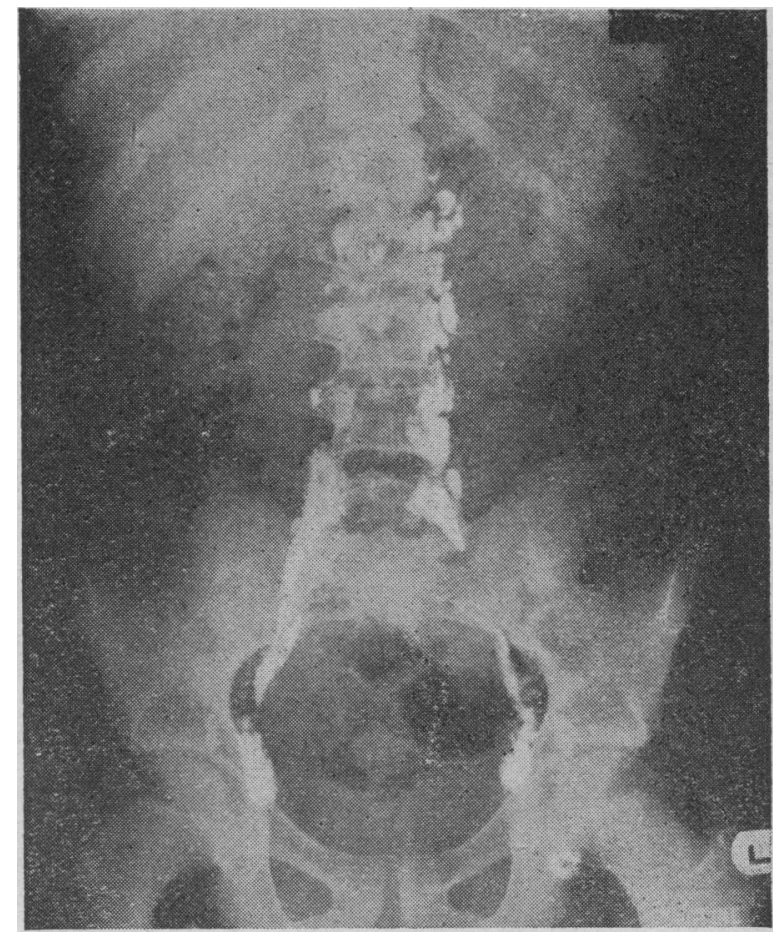

Fig. 6.-Case 1. Lymphangiogram (Dr. R. B. Pridie) showing possible filling defects in the left internal iliac and right para-aortic nodes.

\section{Case 2}

A 35-year-old woman gave a 15-year history of attacks of headache, nausea, and sweating occurring after micturition. She had had intermittent hypertension varying from $160 / 90$ to $240 / 110$ and had been treated with ganglion-blocking agents. This treatment reduced the frequency of hypertensive episodes. In August 1963 a left pyelolithotomy was performed. Intravenous pyelograms at this time showed a filling defect on the left bladder base. The bladder was explored and an apparently malignant tumour found. However, review of the biopsy specimen showed that in fact the lesion was a phaeochromocytoma, and in September 1964 the patient was transferred to the care of Dr. Stanley E. Farley.

At that time she complained of some frequency of micturitionone- to two-hourly by day, two-hourly by night-but had not noticed any haematuria. An intravenous pyelogram showed that the filling defect in the bladder had increased in size. Her blood-pressure was $120 / 80$, and on examination the only significant finding was of a mass in the left side of the pelvis. Cystoscopy showed a tumour some $5-6 \mathrm{~cm}$. in diameter on the left side of the bladder. The left ureteric orifice was normal. A radical partial cystectomy, with reimplantation of the left ureter, was performed on 12 October 1964, and she made a normal recovery. Histological examination confirmed the diagnosis of phaeochromocytoma. Eight months after operation she' was well, with a blood pressure of $100 / 80$ and no evidence of recurrence.

\section{Case 3}

A well-built man aged 50 was first seen in October 1963, giving a history of two episodes of painless haematuria occurring in July 1960 and in July 1963. On each occasion the haematuria was terminal in nature and the quantity of blood passed was small. An 
intravenous pyelogram was normal, but cystoscopy showed a small tumour in the vertex of the bladder. Biopsy revealed a " neoplasm composed of solid acini of polygonal cells with abundant cytoplasmic granules which give positive reactions with a stain for protein, but all other methods, including the chromaffin reaction, are negative. The stroma is sparse and richly vascular. The appearances are those of phaeochromocytoma." The blood-pressure was $165 / 95$ and the urinary excretion of vanillylmandelic acid $7.5 \mathrm{mg} . /$ 24 hours. The histamine provocation test was negative, but in view of the histological evidence the tumour was assumed to be a nonfunctioning phaeochromocytoma.

On 29 October a partial cystectomy was performed. The procedure was entirely uneventful and there was no change in bloodpressure during the procedure. Post-operative progress was uneventful and the patient remained well. Microscopical examination of the tumour was reported as follows: "Bladder wall with overlying mucosa containing a rounded area of a neoplasm composed of solid acini of polygonal cells with small, moderately hyperchromic nuclei, and abundant finely granular cytoplasm. The cytoplasmic granules do not stain with a variety of methods used. The stroma is richly vascular and in places the neoplasm has infiltrated muscle bundles. This is either a phaeochromocytoma or a granular myoblastoma. I think the former most likely" Tissue analysis showed that the tumour contained $3.6 \mathrm{mg}$. of noradrenaline and $0.06 \mathrm{mg}$. of adrenaline, while the bladder wall contained $0.035 \mathrm{mg}$. of noradrenaline and $0.002 \mathrm{mg}$. of adrenaline; all figures are expressed as milligrams per gram of tissue. The high tissue content of noradrenaline confirms the diagnosis of phaeochromocytoma.

\section{Discussion}

Details of the recorded cases of vesical phaeochromocytoma are given in the Table. The tumour may be present at any age, the recorded extremes being 11 and 74 years. The duration of symptoms in some of the cases suggests that the neoplasm may be present in infancy. The sex distribution is approximately equal, and half of the patients had haematuria. Typical symptoms, usually of throbbing or pain in the head after micturition occurred in most cases, though the significance of these symptoms is often not realized until after operation. Occasionally patients have found that these symptoms are more severe when the bladder is full. Partial cystectomy has usually been the treatment of choice and in general the results are good. Followup information relating to most of the recorded cases has been obtained, and it will be seen that further evidence of neoplasm was found in only one case.

Eight years after operation this patient had a recurrence of her hypertension with a urinary vanillylmandelic acid excretion of $11.5 \mathrm{mg}$./24 hours (urine volume 1.5 litres). However, there were no symptoms relating to the urinary tract and cystoscopy was normal. Pyelography and pre-sacral oxygen insufflation revealed no evidence of a suprarenal tumour on either side. The patient was advised to undergo a laparotomy, but declined. At the time of writing her hypertension is controlled medically. It is of course possible that this patient had a multifocal origin of the tumour, but the presence of a metastatic deposit cannot be excluded at the moment.

The distinction between tumours of multifocal origin and those which are malignant may not be easy. In phaeochromocytoma the diagnosis of malignancy does not rest on the cellular characteristics of the tumour nor upon infiltration of the organ of origin, since considerable degrees of cellular variation and local infiltration may be found in tumours which behave in a perfectly benign fashion. To confirm malignancy, secreting cells must be demonstrated at a site where chromaffin

Details of Recorded Cases

\begin{tabular}{|c|c|c|c|c|c|c|c|c|c|c|c|c|}
\hline \multirow{2}{*}{ Source } & \multirow{2}{*}{$\begin{array}{l}\text { Age } \\
\text { and } \\
\text { Sex }\end{array}$} & \multirow{2}{*}{$\begin{array}{c}\text { Duration } \\
\text { of } \\
\text { Symptoms }\end{array}$} & \multirow{2}{*}{$\begin{array}{c}\text { Symp- } \\
\text { toms } \\
\text { of } \\
\text { Hyper- } \\
\text { tension }\end{array}$} & \multirow{2}{*}{\begin{tabular}{|} 
Pain, \\
Faintness, \\
or \\
Throbbing \\
in Head on \\
Micturition
\end{tabular}} & \multirow{2}{*}{$\begin{array}{c}\text { Haema- } \\
\text { turia }\end{array}$} & \multicolumn{2}{|c|}{ Blood-pressure } & \multirow[t]{2}{*}{ Treatment } & \multirow{2}{*}{$\begin{array}{l}\text { Time after } \\
\text { Operation }\end{array}$} & \multirow{2}{*}{$\begin{array}{c}\text { Present } \\
\text { Condition }\end{array}$} & \multirow{2}{*}{$\begin{array}{l}\text { Blood- } \\
\text { pressure }\end{array}$} & \multirow{2}{*}{$\frac{\text { On }}{\text { Examination }}$} \\
\hline & & & & & & Before & After & & & & & \\
\hline $\begin{array}{c}\text { Zimmerman } \\
\text { et al. (1953) }\end{array}$ & $74 \mathrm{~F}$ & 3 years & - & + & + & $220 / 110$ & $180 / 80$ & Partial cystectomy & Died 40 months & & & $\begin{array}{l}\text { No sign of recur- } \\
\text { rence at necropsy }\end{array}$ \\
\hline $\begin{array}{c}\text { et al. (1953) } \\
\text { Rosenberg } \\
\text { (1957) }\end{array}$ & $37 \mathrm{~F}$ & $10 "$ & + & + & - & $\begin{array}{c}170 / 110 \text { to } \\
110 / 70\end{array}$ & $110 / 80$ & " & $\begin{array}{l}\text { later } \\
8 \text { years }\end{array}$ & Alive & & $\begin{array}{c}\text { No evidence of } \\
\text { recurrent tumour }\end{array}$ \\
\hline $\begin{array}{l}\text { Varl and } \\
\text { Rakovec } \\
\text { (1958) }\end{array}$ & $17 \mathrm{~F}$ & - & $?$ & + & - & $280 / 170$ & & " & $\begin{array}{l}\text { Died after } \\
\text { operation }\end{array}$ & & & \\
\hline $\begin{array}{l}\text { Farley and } \\
\text { Smith (1959) }\end{array}$ & $16 \mathrm{~F}$ & 2 years & + & - & + & $\begin{array}{l}160 / 120 \text { to } \\
220 / 120\end{array}$ & $120 / 80$ & Hemicystectomy & 7 years & $\begin{array}{l}\text { Alive and } \\
\text { well }\end{array}$ & $100 / 70$ & $\begin{array}{l}\text { No sign of } \\
\text { recurrence }\end{array}$ \\
\hline $\begin{array}{c}\text { Scott and } \\
\text { Eversole } \\
(1960)\end{array}$ & $14 M$ & 5 hours & - & - & + & $190 / 110$ & $\begin{array}{l}120 / 80 \text { to } \\
150 / 90\end{array}$ & Total cystectomy & $6 "$ & " , & Normal & " \\
\hline $\begin{array}{l}\text { Derome et } \\
\text { al. (1960) }\end{array}$ & $45 M$ & 4 years & + & + & - & $130 / 70$ to & $110 / 70$ & Partial cystectomy & - & - & - & - \\
\hline $\begin{array}{c}\text { Pugh et al. } \\
(1960)\end{array}$ & $53 \mathrm{~F}$ & 1 year & - & - & + & $130 / 90$ & $125 / 75$ & $\begin{array}{l}\text { Open cystodia- } \\
\text { thermy }\end{array}$ & 10 years & $\begin{array}{l}\text { Alive and } \\
\text { well }\end{array}$ & & No sign of \\
\hline$" \quad$, & $68 \mathrm{~F}$ & 6 months & - & - & + & $210 / 110$ & $230 / 150$ & $\begin{array}{l}\text { Transurethral } \\
\text { resection }\end{array}$ & $\begin{array}{l}\text { Died } 3 \text { years } \\
\text { later }\end{array}$ & & & $\begin{array}{l}\text { No clinical evi- } \\
\text { dence of recur- } \\
\text { rence }\end{array}$ \\
\hline ", & $36 \mathrm{~F}$ & $6 \quad$ & + & - & - & $\begin{array}{l}210 / 120 \text { to } \\
150 / 90\end{array}$ & & - & $\begin{array}{l}\text { Died } 44 \text { hours } \\
\text { after cysto- } \\
\text { scopy }\end{array}$ & & & \\
\hline$"$ & $48 F$ & 7 years & - & + & - & $\begin{array}{c}250 / 110 \text { to } \\
270 / 150\end{array}$ & $\begin{array}{l}190 / 100 \text { to } \\
210 / 105\end{array}$ & Partial cystectomy & 8 years & $\begin{array}{l}\text { Alive and } \\
\text { well }\end{array}$ & $\begin{array}{l}\text { Hyper- } \\
\text { tensive }\end{array}$ & $\begin{array}{c}\text { Clinical evidence } \\
\text { of recurrence- } \\
\text { but bladder is } \\
\text { normal. Refu- } \\
\text { sed laparotomy }\end{array}$ \\
\hline Berry and & & 3 & - & + & - & $\begin{array}{l}130 / 80 \text { to } \\
180 / 120\end{array}$ & $130 / 90$ & " & & & $\begin{array}{l}110 / 70 \text { to } \\
140 / 80\end{array}$ & $\begin{array}{l}\text { No sign of } \\
\text { recurrence }\end{array}$ \\
\hline Sivak (1961) & $22 M$ & 7 , & - & + & - & $\begin{array}{l}120 / 80 \text { to } \\
220 / 120\end{array}$ & $120 / 80$ & $\begin{array}{l}\text { Local excision of } \\
\text { tumour }\end{array}$ & $5 \%$ & " , & & $\begin{array}{l}\text { No known } \\
\text { recurrence }\end{array}$ \\
\hline $\begin{array}{l}\text { Micie } e t \\
(1961)\end{array}$ & $19 \mathrm{M}$ & - & $?$ & + & - & $\begin{array}{c}170 / 120 \text { to } \\
260 / 170\end{array}$ & $140 / 90$ & Partial cystectomy & - & - & 一 & - \\
\hline $\begin{array}{l}\text { Tan and } \\
\text { Young } \\
\text { (1962) }\end{array}$ & $11 \mathrm{~F}$ & $\begin{array}{c}\text { Several } \\
\text { years }\end{array}$ & - & + & + & $130 / 80$ & $120 / 80$ & " & - & - & - & - \\
\hline $\begin{array}{l}\text { Poirier and } \\
\text { Robinson } \\
\text { (1962) }\end{array}$ & $39 \mathrm{M}$ & 4 weeks & - & + & + & $150 / 95$ & $120 / 80$ & " & 5 & $\begin{array}{l}\text { Alive and } \\
\text { well }\end{array}$ & $120 / 80$ & $\begin{array}{l}\text { No sign of } \\
\text { recurrence }\end{array}$ \\
\hline $\begin{array}{l}\text { Blair and } \\
\text { Branwood } \\
\text { (1963) }\end{array}$ & $66 M$ & 6 days & - & - & + & $220 / 105$ & $160 / 90$ & ", & 4 & $"$, & & :" \\
\hline $\begin{array}{c}\text { Milliez et al. } \\
\text { (1963) }\end{array}$ & $18 M$ & 10 years & + & + & - & $\begin{array}{c}180 / 100 \text { to } \\
270 / 170\end{array}$ & $180 / 120$ & " & $\begin{array}{l}\text { Died } 3 \text { weeks } \\
\text { after operation }\end{array}$ & & & \\
\hline $\begin{array}{l}\text { Farley (1965) } \\
\text { Case 2 }\end{array}$ & $35 \mathrm{~F}$ & $15 y$ & + & + & - & $240 / 110$ & $100 / 90$ & $\begin{array}{l}\text { Partial cystectomy } \\
\text { + reimplant of } \\
\text { ureter }\end{array}$ & 8 months & $"$, & $100 / 80$ & " \\
\hline $\begin{array}{l}\text { Withycombe } \\
\text { (1965) Case 3 }\end{array}$ & $50 \mathrm{M}$ & 2 & - & - & + & $160 / 90$ to & - & Partial cystectomy & 2 years & ", & - & " \\
\hline Case 1 & $14 M$ & 1 year & - & + & + & $\begin{array}{l}160 / 120 \\
1130 / 95\end{array}$ & $130 / 80$ & , & 9 months & " " & $120 / 80$ & " \\
\hline
\end{tabular}


tissue does not normally occur (Davis et al., 1955). This stipulation is necessary, since benign tumours have a multifocal origin in approximately $10 \%$ of cases, but in such cases tumour cells are confined to tissues which normally contain chromaffin elements. Case 1 was regarded as malignant because phaeochromocytoma cells were found in a lymph node, a site which would not normally contain chromaffin elements. On the other hand, Scott and Eversole (1960) and Farley and Smith (1959) described cases where nodules of tissue completely composed of phaeochromocytoma were found in relation to the iliac vessels, and since no lymphatic tissue was present both of these cases were regarded as being tumours of multifocal origin. Alternatively, it is possible that a lymph node had been involved and had been completely replaced. If this were so it would indicate a very good prognosis in this type of case, since both of these patients were alive and well six and seven years afterwards.

Another feature of Case 1 which may indicate a good prognosis is the fact that the principal metaboliite found in the urine was normetadrenaline. Robinson et al. (1964) found that the precursor dopamine was present in large quantities in the urine of a patient suffering from a malignant phaeochromocytoma and that this substance was again present in the urine when the growth recurred 11 months later. Dopamine is found at an early point on the metabolic chain leading to the production of adrenaline and noradrenaline, and it may be that its presence in the urine indicated a more primitive type of tumour and hence a bad prognosis. No trace of dopamine could be found in the urine of our patient either before or after operation.

Some $10 \%$ of phaeochromocytomas are malignant, and in general the prognosis of these malignant tumours is poor (Hermann and Mornex, 1964). After initial surgical treatment there is usually a period of amelioration lasting for about a year, after which hypertension returns and soon causes death. Longer survivals have been recorded, and one of these was in a child (Cone and Pearson, 1963). In this case, six years after the removal of a tumour from the organ of Zuckerkandl, persisting hypertension led to a further exploration, when recurrent growth was found in the retroperitoneal tissues. For these reasons it was difficult to assess prognosis in our case, and in view of the doubt it was decided to give a course of radiation treatment. Radiation has previously been used in the treatment of malignant recurrences, but not at the time of the original treatment, probably because opportunities for doing this are few and far between. No ill effects have been noted to date, and a careful follow-up will be maintained.

\section{Summary}

Three new cases of phaeochromocytoma of the bladder are reported, bringing the total of recorded cases to 20 . An unusual feature of Case 1 was the presence of a tumour deposit in an iliac lymph node. In view of this finding a course of postoperative radiotherapy was given.

The most common symptom of vesical phaeochromocytoma is a feeling of throbbing or pain in the head during or immediately after micturition. Haematuria occurs rather less frequently. Diagnosis is made by cystoscopy, biopsy, and estimation of urinary catecholamine excretion.

Partial cystectomy is the most satisfactory form of treatment, and the results in most cases have been good.

We wish to thank the many surgeons who have been so kind as to supply us with follow-up information on their patients. In particular we thank Dr. Stanley E. Farley and Mr. J. F. R. Withycombe, who have allowed us to describe previously unpublished cases. We would also like to thank Mr. Cyril Shaldon, who performed the tumour catecholamine assay, and Dr. John Wright, who carried out urinary chromatography studies. Case 1 was presented at a meeting of the Section of Urology at the Royal Society of Medicine.

\section{REFERENCES}

Berry, K. W., and Scott, E. Van Z. (1961). F. Urol. (Baltimore), 85, 156. Blair, D. W., and Branwood, A. W. (1963). Brit. F. Urol., 35, 293.

Cone, T. E., and Pearson, H. A. (1963). Pediatrics, 32, 531 .

Davis, P., Peart, W. S., and van't Hoff, W. (1955). Lancet, 2, 274

Derome, E., Delfoort, R., Auvert, J., Nicoletis, C., and Couvelaire, R. (1960).' Quoted from Milliez et al. (1963).

Farley, S. E. (1965). Personal communication.

and Smith, C. L. (1959). F. Urol. (Baltimore), 81, 130

Hermann, H. X., and Mornex, R. (1964). Human Tumours Secreting Catecholamines. Pergamon Press, Oxford.

Micie, R., Kicic, M., and Adanja, S. (1961). Quoted from Milliez et al. (1963).

Milliez, P., Carrez, P., Lagrue, G., Tcherdakoff, Ph., Samarcq, P., Vigneron, A., and Jacquillat, Cl. (1963). Bull. Soc. méd. Hôp. Paris, 114,1019 .

Poirier, H., and Robinson, J. O. (1962). Brit. F. Urol., 34, 88.

Pugh, R. C. B., Gresham, G. A., and Mullaney, J. (1960). F. Path. Bact.,

Robinson, R., Smith, P., and Whittaker, S. R. F. (1964). Brit. med. Y., 1,1422 .

Rosenberg, L. M. (1957). New Engl. F. Med., 257, 1212.

Scott, W. W. (1965). Personal communication.

$\checkmark$ and Eversole, S. L. (1960). 7. Urol. (Baltimore), 83, 656

Sivak, G. C. (1961). Ibid., 86, 568.

Tan, T. L., and Young, B. W. (1962). Ibid., 87, 63.

Varl, B., and Rakovek, S. L. (1958). Quoted from Milliez et al. (1963).

Withycombe, J. F. R. (1965). Personal communication.

Zimmerman, I. J., Biron, R. E., and MacMahon, H. E. (1953). New Engl. F. Med., 249, 25.
In spite of the increasing frequency of open reduction and plating of forearm bones, the number of reported neurological complications is small. In a large series of cases Burwell and Charnley (1964) reported only one case of posterior interosseous nerve palsy, following the Thomson posterior approach. Anterior interosseous nerve palsy in two cases of closed forearm bone fracture was reported by Warren (1963). The cause there may be damage from the fractured bone ends, from nerve stretch in the course of manipulation or at the time of injury, or from compression due to haematoma in the deep forearm space. Though the superficial radial nerve is of ten temporarily damaged during dissection or during retraction of the brachio-

* From the Southern General Hospital, Glasgow. radialis in the anterior Henry approach, other nerve lesions do not seem to be commonly described. Four motor-nerve injuries following plating of forearm bones are described. They were encountered over a period of several years, but no attempt is here made to indicate the frequency of such lesions in relation to a series of uncomplicated forearm operations. Involvement of the part of the anterior interosseous nerve supplying the flexor pollicis longus occurred in three patients and of the posterior interosseous nerve trunk in one.

\section{Case Reports}

Case 1 (Fig. 1).-Primary plating and grafting of radius and ulna was carried out three days after injury. The radial fracture 